\title{
The Predictive Role of Self-efficacy, Gender, and Cyber Victimization on Cyber Bullying in Adolescents
}

\author{
Tuğba Yılmaz Bingöl \\ Faculty of Education, Fatih Sultan Mehmet Foundation University, Turkey
}

Copyright $(2018$ by authors, all rights reserved. Authors agree that this article remains permanently open access under the terms of the Creative Commons Attribution License 4.0 International License

\begin{abstract}
In this study, the predictive role of self-efficacy, gender and cyber victimization on cyber bullying in adolescents was examined. Examining whether the participants' mean self-efficacy, cyberbullying and cyber victimization scores differ significantly by gender are the sub-objectives of the research. The present study which was designed with a relational screening model was carried out with 185 eight graders. T-test and multiple regression analysis were used to analyze the data and analyses were carried out via IBM SPSS Statistics 23. Findings indicated that the means score of participants did not differ significantly in terms of gender. The independent variables were able to account for $23 \%$ of the variance in cyber bullying. The relative importance order of the predictor variables on cyber bullying was cyber victimization, gender, and self-efficacy. The t-test results on the significance of the regression coefficients indicated that among predictive variables cyber victimization is a significant predictor of cyber bullying, but self-efficacy and gender have no significant effect.
\end{abstract}

Keywords Self-efficacy, Cyber Bullying, Cyber Victimization

\section{Introduction}

Cyberbullying have increased since the students began to use social media to complete social interactions with their peers. Although the prevalence of cyberbullying has been changed depending on the criterions that are used, the country in which the data are collected and the age of participants; it is indicated that cyberbullying is increasing due to the overwhelming use of the social media [1]. Kowalski, Limber and Agatston [2] demonstrated that between $10 \%$ and $\% 40$ of the students exposed to cyber bullying. In our country, there are research results showing that cyber bullying is not a rare event $[3,4,5,6]$. Cyberbullying is similar to traditional bullying but it is a subcategory of aggressive behavior that involves intentionally harmful repeated behavior against weak individuals or groups [7].

Cyberbullying differs from traditional bullying in several ways. It occurs in several forms of electronic communication such as e-mail, online game sites, chat rooms, digital images, websites and instant messaging via smart phones, computers and tablets [2]. However, victims of cyberbullying experience several negative psychosocial consequences that are similar to victims of traditional bullying including depression, low self-esteem, anxiety, impairment of concentration, personal injury, suicidal thoughts and suicide $[8,9]$.

A combination of cyberbullying with traditional bullying is increasingly conceptualized as immoral behavior $[10,11,12]$. Morality is a concept about human welfare, justice and rights [13]. Bullying, which involves repeated intentional harm to a weak person, is an immoral behavior that affects the well-being and rights of the victims. Cyberbullying is generally indirect rather than face- to face and the bully can be unknown, so there is no social barrier like in traditional bullying. This situation increases the role of self-regulatory factors in cyberbullying which are significantly important in the connection between the exposure to the bullying and morality.

According to Bandura [14] moral disengagement can be mentioned as a representative approach to morality involving self-regulation processes. Moral disengagement allows to selective activation and disengagement of internal standards and permits different types of behavior with the same moral standards [15]. In the context of bullying, moral disengagement is a process that allows those who condemn the bullying to bully others in an un-respectful way through selective deactivation of their moral standards in certain parts of being bullied [16]. The concept of self-efficacy that is related with these self-regulatory processes is the basic concept of social cognitive theory and is at the core of personal representation [17]. 
Individuals have self-efficacy beliefs in different areas. The self-efficacy beliefs in various areas influence the behaviors of a person in that area. In other words, self-efficacy beliefs are of a person about his/her capacity to perform or complete a task. If a person has a belief that he or she has capability to engage cyberbullying is called as cyberbullying self-efficacy beliefs. If a person believes he/she can solve mathematical problems and continue to try without giving up when he/she failed to solve that is called mathematics self-efficacy. Self-efficacy beliefs can be high in an area, while they can be low in another area.

Bandura [17]) stated the importance of children having information about their talents. He emphasized that this can be achieved through improve their communication with their surroundings. Children have to develop their own physical and cognitive abilities, social skills and the ability to cope with various problems of everyday life. Although self-efficacy beliefs have a regulatory role in all transitions of life, they especially become more important in adolescence [18], because adolescence which is a period of transition from childhood to adulthood, adjustment to physical and emotional changes and adaptation to new responsibilities, also brings new challenges and difficulties. In this period, adult roles become more salient. They become more active in the society, have more responsibility and have more varied roles than childhood. Adolescence is one of the most important periods in determining the roles of individuals in their life. Adolescence is defined as the period of psychosocial conflict. Although no period of life is ever free of problems, adolescence is a period of conflict which characterized with stress and anger.

Based on the explanations above and the relationships among self-efficacy, cyberbullying/ cyber victimization and adolescence this study was conducted to examine the predictive roles of general self-efficacy which has relations with several variables, cyber victimization and gender on cyberbullying in eight-grade students. In addition the sub-objectives of the research were as follows:

- What are the levels of self-efficacy, cyberbullying and cyber victimization of participants?

- Does the participants' self-efficacy scores differ significantly by gender?

- Does the participants' cyber victimization scores differ significantly by gender?

- Does the participants' cyber bullying scores differ significantly by gender?

\section{Materials and Methods}

\subsection{Research Model}

This study was designed with a relational screening model that aims to determine the existence and/or degree of covariance between two or more variables [19].

\subsection{Study Group}

The study group of the study was composed of 185 eight-grade students in Üsküdar district of Istanbul. The study group consists of volunteer participants and was selected taking into account the level of representation of the universe. Of the participants $41.62 \%(\mathrm{~N}=77)$ were female and $58.38 \%(\mathrm{~N}=108)$ were male.

\subsection{Data Collection Tools}

The Self-Efficacy Scale: The Self-efficacy Scale (SE) which was developed and validated by Vardarli [20] for middle school students was used to measure self-efficacy levels of participants. The Cronbach alpha coefficient was calculated as .87 . The scale consists of 10 items which aims to assess to what extent individuals perceive themselves as efficient to cope with difficulties or challenges and are rated on a 4-point scale. The scores range from 10 to 40 . Higher indicate greater greater self-efficacy perceptions.

The Cyberbully/ Victim Scale: The Cyberbully/ Victim Scale was developed by Ayas and Horzum [21] to determine cyber bully behaviors of middle school students. The 19-item scale consists of six subscales. The internal consistency coefficients of cyber victim and bully dimensions were calculated as .81 . The scale is a 5 -point Likert-type scale. Scores for scale can range from 19 to 95.

\subsection{Data Collection}

The data collection tools are applied by the researcher in a regular class hour. All the participants were volunteers to fill out the data set. The participants were informed by the researcher about how to respond the measurements. It took 20 minutes to complete the questionnaires.

\subsection{Data Analysis}

As a result of the preliminary analysis, t-test was used to examine the significance of difference between mean scores of participants' in terms of gender; multiple regression analysis was used to determine the effect of the independent variables (self-efficacy, gender and cyber victimization) on the dependent variable (cyberbullying). The hypothesis was tested at .05 level of significance. In the present study analyses were carried out via IBM SPSS Statistics 23.

\section{Findings}

General characteristics of the sample with respect to the variables of the study are explored by means of descriptive statistics. Basic descriptive statistics for all study variables of interest are presented in Table 1 
Table 1. Descriptive Statistics for Study Variables

\begin{tabular}{|c|c|c|c|c|c|}
\hline & $\mathrm{N}$ & Mean & Sd & Skewness & Kurtosis \\
\hline $\mathrm{SE}$ & 188 & 29,41 & 6,38 & -607 &, 087 \\
\hline $\mathrm{CB}$ & 177 & 93,14 & 2,75 & $-1,533$ & 1,34 \\
\hline $\mathrm{CV}$ & 185 & 92 & 3,59 & $-1,292$ & 1,07 \\
\hline
\end{tabular}

( $\mathrm{SE}=$ Self-efficacy, $\mathrm{CB}=$ Cyberbullying, $\mathrm{CV}=\mathrm{Cyber}$ victimization)

When Table 1 is examined, it can be seen that the mean self-efficacy, cyberbullying and cyber victimization mean scores of participants were 29.41 $(\mathrm{Sd}=6.38), 93.14(\mathrm{Sd}=$ $2,753)$ and $92(\mathrm{Sd}=3,59)$ respectively. According to Tabachnick and Fidell [22], the acceptable range of the skewness and kurtosis statistics which suggesting that the data did not violate the normality is between +1.5 and 1.5. When the table is examined, it is seen that data were distributed normally. The scores that can be obtained from the self-efficacy scale range from 10 to 40 . Thus, it can be said that participants tended to exhibit relatively high level of self-efficacy. The lowest and highest scores that can be obtained from the Cyberbully/ Victim Scale are 19 and 95 respectively. Higher scores indicate greater cyberbullying/ victimization. Therefore, it can be said that participants tended to exhibit high level of self-efficacy cyberbullying/ victimization.

The results of $t$ test to determine whether a significant self-efficacy mean difference exists according to gender were presented in Table 2 .

Table 2. T test results for self-efficacy mean differences according to gender

\begin{tabular}{|c|c|c|c|c|c|c|}
\hline Gender & $\mathrm{N}$ & Mean & $\mathrm{Sd}$ & $\mathrm{sd}$ & $\mathrm{t}$ & $\mathrm{p}$ \\
\hline Female & 78 & 29,07 & 6,47 & 186 & -610 &, 54 \\
\hline Male & 110 & 29,65 & 6,34 & & & \\
\hline
\end{tabular}

When the table 2 is examined, it can be seen that-test analysis results did not show a statistically significant difference in means between female and male students in terms of the self-efficacy $(\mathrm{p}>.05)$.

The results of $t$ test to determine whether a significant cyberbullying mean difference exists according to gender were presented in Table 3 .
Table 3. T Test Results for Cyberbullying Mean Differences According to Gender

\begin{tabular}{|c|c|c|c|c|c|c|}
\hline Gender & $\mathrm{N}$ & Mean & $\mathrm{S}$ & $\mathrm{sd}$ & $\mathrm{t}$ & $\mathrm{p}$ \\
\hline Female & 72 & 93,53 & 2,68 & 175 & 1,55 &, 12 \\
\hline Male & 105 & 92,88 & 2,77 & & & \\
\hline
\end{tabular}

When the table 3 is examined, it can be seen that-test analysis results did not show a statistically significant difference in means between female and male students in terms of the cyberbullying ( $\mathrm{p}>.05)$.

The results of $t$ test to determine whether a significant cyber victimization mean difference exists according to gender were presented in Table 4.

Table 4. T Test Results for Cyber Victimization Mean Differences According to Gender

\begin{tabular}{|c|c|c|c|c|c|c|}
\hline Gender & $\mathrm{N}$ & Mean & $\mathrm{S}$ & $\mathrm{sd}$ & $\mathrm{t}$ & $\mathrm{p}$ \\
\hline Female & 77 & 92,21 & 3,54 & 183 & 663 &, 50 \\
\hline Male & 108 & 91,85 & 3,63 & & & \\
\hline
\end{tabular}

When the table 4 is examined, it can be seen that-test analysis results did not show a statistically significant difference in means between female and male students in terms of the cyber victimization ( $\mathrm{p}>.05)$.

The regression analysis results to test the predictive roles of self-efficacy, gender and cyber victimization on cyberbullying are presented in Table 5 .

When Table 5 is examined, it is found that there is a significant relationship between cyber victimization, self-efficacy, gender and cyber bullying scores $(\mathrm{R}=, 484$, $\mathrm{R} 2=, 234, \mathrm{p}<.001)$. The three predictor model was able to account for $23 \%$ of the variance in cyber bullying. According to the standardized regression coefficient $(\beta)$, cyber victimization has the highest impact and contributes most in the cyberbullying, followed by gender, whereas self-efficacy is a minor factor. The t-test results on the significance of the regression coefficients indicated that among predictive variables cyber victimization is a significant predictor of cyber bullying. On the other hand it was found that self-efficacy and gender have no significant effect.

Table 5. The Results of Multiple Regression Analysis of Independent Predictors of Cyberbullying

\begin{tabular}{|c|c|c|c|c|c|c|c|}
\hline Variable & $\mathrm{B}$ & Standart error & $\beta$ & $\mathrm{T}$ & $\mathrm{p}$ & Binary $r$ & Partial $\mathrm{r}$ \\
\hline Constant & 58,12 & 5,29 & - & 10,98 &, 00 & - & - \\
\hline $\mathrm{CV}$ & ,38 &, 05 &, 46 & 6,90 &, 00 &, 47 & ,46 \\
\hline $\mathrm{SE}$ &, 00 &, 02 &, 00 &, 13 &, 89 &, 03 &, 01 \\
\hline Gender &,- 58 &, 36 &,- 10 & $-, 1,58$ &, 11 &,- 13 &,- 12 \\
\hline
\end{tabular}

$\mathrm{R}=, 484 \mathrm{R}^{2}=, 234 \mathrm{~F}_{(3-170)}=17,343 \mathrm{p}=, 000$ 


\section{Discussion and Conclusion}

The findings of the study indicated that participants reported high level of self-efficacy, cyberbullying and cyber victimization. It was also found that the mean self-efficacy scores of participants did not differ according to gender. Previous studies have also supported this finding [23, 24, 25]. However, some studies have provided evidence that males have higher self-efficacy than females $[26,27,28]$. Considering the effects of identity development and environmental factors on self-efficacy, it is thought that due to the fact that the adolescents are in the most formative phase of identity development, the total self-efficacy mean scores of male and female students are similar.

Another findings of the study showed that there is no significant difference between the mean cyberbullying/victimization scores of male and female students. While some previous findings are consisted with the current results $[29,30]$ some other studies have found contradictory results to this study. Eksi [31] demonstrated that boys do more cyber bullying than girls. Peker [32] considered gender as a risk factor for cyberbullying/ victimization. In another study conducted by Uysal and Yllmaz-Bingöl [33] it was found that males exhibit more risk-taking behavior than females. Therefore it can be excepted male students to do more cyber bullying behavior. However, these findings do not support the result of the current research. It is thought that further studies which aim to describe the characteristics of cyber victims may explain contradictory results. It may be possible for girls to experience more cyberbullying to lead them also to do more cyberbullying.

The results of the current study also indicated that cyber victimization is a significant predictor of cyber bullying but self-efficacy and gender didn't predict cyberbullying significantly. Various studies have examined the predictors of cyberbullying. In their study Bussey, Fitzpatrick, and Raman [1] investigated the relationship between cyberbullying self-efficacy beliefs and cyberbullying. They found that students who believe in their cyberbullying capabilities high level of cyberbullying are more likely to do cyberbullying. In a study conducted by Eksi [31] 508 high school students, it was found that cyberbullying was predicted by narcissistic personality traits. Dilmac [34] who aimed to investigate the relationship between cyberbullying and personality traits indicated that endurance is a significant predictor of cyberbullying. Similarly Rahey [35] also remarked that as endurance increases cyberbullying decreases. In the study conducted by Çetin, Eroğlu, Peker, Akbaba and Pepsoy [36] with 258 high school students it was found that students who are high in relational-interdependent self-construal are significantly more likely to avoid cyberbullying. Peker, Eroğlu and Ada [37] demonstrated that empathic tendency, gender and perceived academic achievement are the predictors of cyberbullying. Self-efficacy has a negative relationship with concepts such as risk taking, psychological distress [17]. Thus it is expected that individuals who believe in their capabilities to cope with difficulties are more likely to avoid engaging cyberbullying. Nevertheless, the result of this study indicating that self-efficacy is not a significant predictor of cyberbullying is different from previous results. However, Arıcak [3] and Şahin et al [38] have remarked that there is a positive relationship between cyber bullying and cyber victimization. These results are consistent with the findings of current study which indicated that cyber victimization is a significant predictor of cyberbullying. It may be thought that individuals who are exposed to cyberbullying may engage in cyberbullying behavior to feel more powerful and to seek revenge.

This research is important in terms of aiming to describe the relationship between cyberbullying to self-efficacy. However, the current study is limited in terms of sampling. Further studies with larger sample size will be needed to confirm these results and to make contribution to the field. Future studies may examine the relationship between cyberbullying and personality traits. Path analysis studies on variables that may have an impact on cyberbullying may also be useful to understand this construct.

\section{REFERENCES}

[1] Bussey, K., Fitzpatrick, S., \& Raman, A. (2015). The role of moral disengagement and self-efficacy in cyberbullying. Journal of School Violence, 14, 1, 30-46. DOI: $10.1080 / 15388220.2014 .954045$

[2] Kowalski, R. M., Limber, S. P., Limber, S. P., \& Agatston, P. W. (2012). Cyberbullying: Bullying in the digital age.UK: John Wiley \& Sons.

[3] Arıcak, O.T. (2009). Psychiatric symptomatology as a predictor of cyberbullying among university students. Eurasian Journal of Educational Research, 34, 167-184.

[4] Ayas, T. (2011). 'Lise öğrencilerinin sanal zorba ve mağdur olma yaygınlığı', 11. Ulusal Psikolojik Danışma ve Rehberlik Kongresi, 3-5 Ekim, İzmir.

[5] Ayas, T., \& Horzum, M. B. (2012). İlköğretim öğrencilerinin sanal zorba ve mağdur olma durumu. İlköğretim Online, 11(2).

[6] Erdur-Baker, Ö. (2010). Cyberbullying and its correlation to traditional bullying, gender and frequent and risky usage of internet-mediated communication tools. New media \& society, 12(1), 109-125.

[7] Nocentini, A., Calmaestra, J., Schultze-Krumbholz, A., Scheithauer, H., Ortega, R., \& Menesini, E. (2010). Cyberbullying: Labels, behaviours and definition in three European countries. Journal of Psychologists and Counsellors in Schools, 20(2), 129-142. 
[8] Bauman, S., \& Newman, M. L. (2013). Testing assumptions about cyberbullying: Perceived distress associated with acts of conventional and cyber bullying. Psychology of violence, $3(1), 27$.

[9] Kowalski, R. M., Limber, S. P., Limber. (2007). Electronic bullying among middle school students. Journal of Adolescent Health. 41, 6, 22-30.

http://dx.doi.org/10.1016/j.jadohealth.2007.08.017

[10] Arsenio, W. F., \& Lemerise, E. A. (2004). Aggression and moral development: Integrating social information processing and moral domain models. Child development, 75(4), 987-1002.

[11] Gini, G. (2008). Italian elementary and middle school students' blaming the victim of bullying and perception of school moral acceptance. The Elementary School Journal, 108, 335-354. doi:10.1086/528975 .

[12] Hymel, S., Schonert-Reichl, K. A., Bonanno, R. A., Vaillancourt, T., \& Rocke Henderson, N. (2010). Bullying and morality: Understanding how good kids can behave badly. In S. R. Jimerson, S. M. Swearer, \& D. L. Espelage (Eds.), Handbook of bullying in schools: An international perspective (pp. 101-118). New York, NY: Routledge.

[13] Tisak, M. S., Tisak, J., \& Goldstein, S. E. (2010). Aggression, delinquency, and morality: A social-cognitive perspective. In M. Killen \& J. Smetana (Eds.), Handbook of moral development (pp. 611-632). New York, NY: Psychology.

[14] Bandura, A. (2002). Social cognitive theory in cultural context. Applied psychology, 51(2), 269-290.

[15] Bandura, A., Barbaranelli, C., Caprara, G. V., \& Pastorelli, C. (1996). Multifaceted impact of self-efficacy beliefs on academic functioning. Child development, 67(3), 1206-1222.

[16] Paciello, M., Fida, R., Tramontano, C., Lupinetti, C., \& Caprara, G. V. (2008). Stability and change of moral disengagement and its impact on aggression and violence in late adolescence. Child Development, 79(5), 1288-1309.

[17] Bandura, A. (1977). Self-efficacy: toward a unifying theory of behavioral change. Psychological review, 84(2), 191.

[18] Caprara, G. V., Scabini, E., Barbaranelli, C., Pastorelli, C., Regalia, C., \& Bandura, A. (1999). Autoefficacia percepita emotiva e interpersonale e buon funzionamento sociale. Giornale italiano di Psicologia, 26(4), 769-790.

[19] Karasar, N. (1995). Bilimsel araştırma yöntemi (7. bs.). Ankara: 3A Egitim Araçtirma Egitim Damçmanlik Ltd.

[20] Vardarlı, G. (2005). İlköğretim ikinci kademe ögrencilerinin öz-yeterlik düzeylerinin yordanması. Yayınlanmamış Yüksek Lisans Tezi, İzmir: Ege Üniversitesi Sosyal Bilimler Enstitüsü.

[21] Ayas, T., \& Horzum, M. B. (2010). Sanal zorba/kurban ölçek geliştirme çalışması. Akademik Bakış Dergisi, 19, $1-17$.

[22] Tabachnick, B. G., \& Fidell, L. S. (2013). Using multivariate statistics. 6th Edit. Boston: Pearson Education.

[23] Telef, B. B., \& Karaca, R. (2011). Ergenlerin öz-yeterliklerinin ve psikolojik semptomlarının incelenmesi/ Adolescents' self-efficacy and psychological symptoms' investigation. Mustafa Kemal Üniversitesi Sosyal Bilimler Enstitüsü Dergisi, 8(16).

[24] Ünal-Keskin, G., Orgun, F. (2006). Examination of strategies to cope with self-efficacy-competence levels of students. Anatolian Journal of Psychiatry, 2006; 7:92-99.

[25] Yılmaz-Bingöl, T., Vural-Batık, M., Fırınc1-Kodaz, A., \&Hoşoğlu, R. (2017). 'Üniversite öğrencilerinin genel-öz-yeterlik algıları', 17-19 July, Berlin.

[26] Aydiner, B. B. (2011). The relationship between sub-dimensions of the life goals with general self-efficacy, life-satisfaction and some variables. Unpublished master's thesis, Sakarya Üniversitesi, Eğitim Bilimleri Enstitüsü, Sakarya.

https://tez.yok.gov.tr/UlusalTezMerkezi/adresindenedinilm iştir.

[27] Çetin, B. (2007). The effects of new primary educational curricula applications (2005) on the 4th and 5th grade elementary students' habits of studying and their self-efficacy level, and the opinions of those students about the new curricula. Unpublished doctorate dissertation, Marmara Üniversitesi, Eğitim Bilimleri Enstitüsü, İstanbul.

[28] Fallan, L.\& Opstad, L. (2016). Student self-efficacy and gender-personality interactions. International Journal of Higher Education, 5, 3, 32-44.

[29] Hinduja, S., Patchin, J. W. (2008). Cyberbullying: An exploratory analysis of factors related to offending and victimization. Deviant Behavior, 29, 2, 129-156.

[30] Topçu, Ç., Erdur-Baker, Ö., \& Çapa-Aydin, Y. (2008). Examination of cyberbullying experiences among Turkish students from different school types. CyberPsychology \& Behavior, 11(6), 643-648.

[31] Ekşi, F. (2012). Narsistik kişilik özelliklerinin internet bağımlılığ1 ve siber zorbalığg yordama düzeyinin yol analizi ile incelenmesi. Kuram ve Uygulamada Eğitim Bilimleri, $12,3,1683-1706$.

[32] Peker, A. (2015). Analyzing the risk factors predicting the cyberbullying status of secondary school students. Egitim Ve Bilim, 40(181).

[33] Uysal, R. \& Y1lmaz-Bingöl, T. (2014). Examining adolescents' risk taking behavior in terms of self-efficacy and other variables. Akademik Sosyal Araştırmalar Dergisi, Y11: 2, Say1: 8, Aralık 2014, s. 573-582.

[34] Dilmaç, B. (2009). Sanal Zorbalığı Yordayan Psikolojik İhtiyaçlar: Lisans Öğrencileri İçin Bir Ön Çalışma. Kuram ve Uygulamada Eğitim Bilimleri, 9, 3, 1291-1325.

[35] Rahey, L. L. A. (2007). The direct and moderating effect of bullying on adolescent health. (Doctoral dissertation). Queen's University: Kingston, Ontario, Canada.

[36] Çetin, B., Eroğlu, Y., Peker, A., Akbaba, S., \& Pepsoy, S. (2012). Ergenlerde ilişkisel-karş1lıklı bağımlı benlik kurgusu, siber zorbalık ve psikolojik uyumsuzluk arasındaki ilişkinin incelenmesi. Kuram ve Uygulamada Eğitim Bilimleri, 12, 2, 637-653.

[37] Peker, A., Eroğlu, Y., \& Ada, Ş. (2012). Ergenlerde siber zorbalığın ve mağduriyetin yordayıcılarının incelenmesi. Abant İzzet Baysal Üniversitesi Eğitim Fakültesi Dergisi. 
$12,2,185-206$

[38] Şahin, M., SARI, S. V., Ömer, Ö. Z. E. R., \& ER, S. H. (2010). Lise öğrencilerinin siber zorba davranışlarda bulunma ve maruz kalma durumlarına ilişkin görüşleri. Süleyman Demirel Üniversitesi Fen-Edebiyat Fakültesi Sosyal Bilimler Dergisi, 2010(21). 